demonstrates most perfectly the proportionality of the spaces described to the squares of the times employed in their description. In this connection should also be mentioned his valuable inventions of the dynameter of rotation, and the dynametric crank. In 1853-1854, Morin communicated a most valuable series of experimental results on the resistance of building materials, by means of which he established several important principles of practical application in the solution of architectural problems. Among less prominent researches, mention should be made of those on gun-cotton (I 849), on the production of carbon monoxide in rooms heated by iron stoves (1869), and on the preservation of flour (1870).

As an author, General Morin is best known by his two works "Leçons de Mécanique pratique" and "Résistance des Matériaux" ( 1853 ) ; as well as by able reports on various technical and military inventions referred to him by the French War Department and the Academy of Sciences.

General Morin's executive abilities have long been appreciated and utilised at Paris. After occupying for some time the chair of mechanics at the Conservatoire des Arts et Métiers, he was appointed director of this jmportant establishment in 1849 . Under the thirty years of his régime the efficiency and influence of the Conservatoire has been vastly increased and strengthened, until it has become the chief auxiliary in elevating and educating the artisan classes of the French capital. In I 855, General Morin occupied the difficult and trying position of president of the commission for the first Universal Exhibition held at Paris. In 1862 he was elected president of the French Society of Civil Engineers. Since 1858 , he has been a grand officer in the Legion of Honour. He was elected a member of the French Academy of Sciences in 1843, as successor to Coriolis in the section of mechanics, and has always maintained an influential position in the actions of that body.

T. H. N.

\section{PRE-HISTORIC MAN IN JAPAN 1}

$M$ R. MORSE seems to claim for the shell-mounds 1 lately investigated by him at Omori (wrongly spelled Omori throughout his monograph), a small village a few miles from Yedo, an antiquity as high as that of the Danish kitchen-middens. I cannot help thinking the conclusion a hasty one, or, at least, not warranted by the facts set forth in the monograph in question. The shellmounds are therein described as situate about half a mile from the shore, and the principal heap is stated to be some ninety metres in length by about four metres in breadth. It is now, I believe, completely swept away.

These mounds consist for the most part of shells, little, if at all, distinguishable from what are still to be found in abundance along the shores of the Gulf of Yedo, mixed with fragments of pottery, implements of stone and horn, clay ornaments and "tablets," together with bones of the monkey, bear, deer, dog, wild boar, and of man, the human bones or their fragments being nearly as numerous as those of the remaining mammals. Of the eighteen lithographed plates with which the monograph is embellished, fifteen are devoted to the delineation of fragments of pottery, and one cannot but regret that some of this space was not used for drawings of the bones and shells, especially of such of the latter as are stated to belong to extinct species. A figure, too, of the right lower jaw of the "large baboon-like ape" alleged to be "certainly unlike anything found in Japan to day," and supposed to belong to a species of cynopithicus (sic), would have been a most welcome addition. The fragments of pottery, of which drawings are given, do not 1 "Memoirs of the Science Department, University of Tokio, Japan," vol. i. Fart r. "Shell-mounds of Omori." By E. S. Morse, Prufessor of
Zoology, University of Tokio, Japan. Published by the University of Zoology, University of Tokio, Japan. Published by
Tokio, Japan. Nisshusha Print:ng Office, 2539 ( 1879 ). tell us much. A coarse ware, with not very dissimilar ornamentation, is not hard to meet with in country villages, and inferior specimens of the well-known "banko" faience are commonly adorned with lines, strokes, dots, and "hatchings," that bear no little resem blance to those delineated in Mr. Morse's figures. The drawings and descriptions of the stone implements do not help us towards pronouncing upon their antiquity. The distance of the shell-mounds from the shore is in no way remarkable, and does not of itself prove any change of level since the period of their accumulation. Clear evidence, however, but of a very different nature, may be found in the neighbourhood of Yedo and Yokohama, of alternate elevations and depressions of the land, and it is probable that at the present day the waters of the Gulf of Yedo are slowly receding. Remains and traces of shellheaps of quite modern date are common enough in the provinces of Musashi and Sagami, and doubtless elsewhere also, at a considerable distance from the shore, even far inland. I am inclined to believe that the dog is not indigenous to Japan, but has been introduced from China. The Japanese name "inu," indeed, seems to be connected with the Chinese word for dog "Kiuen" (cf. Greek xú $\omega \nu$, Latin canis). ${ }^{1}$ Lastly, the "adzuma," or eastern region of the main island was probably peopled shiefly by an Aino race, up to the fourteenth or fifteenth centuries. Yedo was not founded before the close of the sixteenth century. Legend, indeed, tells us that Nikkò was "opened" by the Buddhist saint, Shôdô shônin, in the eighth century, and that shrines were erected there towards the middle of the ninth century; but it seems probable that up to at least as late as the fourteenth century the country east of the Hakoné Pass was principally inhabited by an aboriginal race.

Upon these grounds, and in the absence of materials for instituting a comparison between the mound-shells and recent forms, I should hesitate to assign a higher antiquity to the Ômori heaps than the thirteenth or fourteenth century, and it seems to me more probable that they were the work of an Aino race than of contemporaries of the builders of the Danish middens. The question of cannibalism I have not space to discuss. We know so little about the Ainos and their customs that it is impossible to say whether these might or might not explain the occurrence of human bones in the heaps without loading the memory of a docile and gentle folk with the odious charge of anthropophagism.

Some of Mr. Morse's statements require considerable modification. The chronicles of Japan do not run back for I,500 years, or for anything like that period. The legends run back, it is true, much farther, some millions of years indeed, but the oldest Japanese book extant, the "Kojiki," a mere collection of myths, was compiled in the eightl century of our era. The art of writing was introduced from China, hardly earlier than the sixth century, and the annals of Japan up to quite recently presented such a mixture of fact and fable that they are of but small historical value. I must add that the statement in the preface that "there is no other country in the world where so great a number of gentlemen interested in archæology can be found as in Japan," is to me a most surprising one.

The lithographs are excellent, and the paper and typography are good ; but surely Mr. Morse will hardly please his Japanese friends by patting them upon the back, as if they were clever savages, because they have performed the not very extraordinary feat of making paper with European machinery, and under European superintend. ence or instruction, and the still more insignificant one, for some ten or fifteen years familiar to the native compositors of a dozen printing offices in Yokohama, of printing a few score pages of English with tolerable clearness and accuracy. FREDK. V. DICKINS 